\title{
Hypoxia Conditioning for High-Altitude Pre-acclimatization
}

\author{
Martin Burtscher ${ }^{1,2} \mathbb{D}$. Grégoire P. Millet ${ }^{3,4}$. Johannes Burtscher ${ }^{3,4}$
}

Received: 1 August 2021 / Accepted: 15 October 2021 / Published online: 9 January 2022

(c) The Author(s) 2022

\begin{abstract}
Purpose Main purposes of pre-acclimatization by hypoxia conditioning (HC) are the prevention of high-altitude illnesses and maintenance of aerobic exercise performance. However, robust evidence for those effects or evidence-based guidelines for exposure strategies, including recommendations to ensure safety, are largely lacking. Therefore, we summarize the current knowledge on the physiology of acclimatization to hypoxia and $\mathrm{HC}$ with the aim to derive implications for pre-acclimatization strategies before going on high-altitude treks and expeditions.

Methods Based on the literature search and personal experience, core studies and important observations have been selected in order to present a balanced view on the current knowledge of high-altitude illnesses and the acclimatization process, specifically focusing on pre-acclimatization strategies by HC.

Results and Conclusions It may be concluded that in certain cases even short periods (e.g., $7 \mathrm{~h}$ ) of pre-acclimatization by $\mathrm{HC}$ are effective, but longer periods (e.g., $>60 \mathrm{~h}$ ) are needed to elicit more robust effects. About $300 \mathrm{~h}$ of HC (intermittently applied) may be the optimal preparation for extreme altitude sojourns, although every additional hour spent in hypoxia may confer further benefits. The inclusion of hypobaric exposures (i.e., real altitude) in pre-acclimatization protocols could further increase their efficacy. The level of simulated altitude is progressively increased or individually adjusted ideally. HC should not be terminated earlier than 1-2 weeks before altitude sojourn. Medical monitoring of the pre-acclimatization program is strongly recommended.
\end{abstract}

Keywords Hypoxia $\cdot$ Normobaric $\cdot$ Hypobaric $\cdot$ Conditioning $\cdot$ Acclimatization $\cdot$ Altitude

\section{Introduction}

When going to high altitudes, proper acclimatization by slow ascent rates is a prerequisite in order to avoid highaltitude illnesses. This process can be supported by preceding hypoxia exposures at real altitude and/or in simulated altitude. We here define "modern" pre-acclimatization strategies as approaches that do not require actual high-altitude environments but rather take advantage of controlled indoor or laboratory conditions or tools to mimic aspects of such

Martin Burtscher

Martin.burtscher@uibk.ac.at

University of Innsbruck, 6020 Innsbruck, Austria

2 Austrian Society for Alpine and High-Altitude Medicine, 6020 Innsbruck, Austria

3 Institute of Sport Sciences, University of Lausanne, 1015 Lausanne, Switzerland

4 Department of Biomedical Sciences, University of Lausanne, 1015 Lausanne, Switzerland environments to prepare individuals to high altitude exposures. The scientific interest in and practical applications of these "modern" pre-acclimatization strategies are actually not that new [16, 23, 48, 95], but still give rise to controversy among the "high-altitude scientific community" [63, 112]. In contrast to traditional acclimatization concepts, including slow ascent and staging on the target mountain with or without preceding (pre)acclimatization at a different, more convenient (less hostile) high-altitude location [7, 77], preacclimatization methods by the use of simulated altitude exposures (hypoxia conditioning, HC) can be incorporated in daily life at home [23, 95]. For technical reasons (hypobaria), simulated altitude exposures in hypobaric chambers are almost exclusively used for scientific research [84, 97], rendering normobaric hypoxia within chambers or tents as well as with mask systems, the preferable means for easyto-use pre-acclimatization purposes. Traditional acclimatization guidelines commonly suggest not to exceed an ascent rate of $500 \mathrm{~m}$ gain in altitude per day above $2500 \mathrm{~m}$, including extra rest days for every additional ascent of 
1000-1500 m [7, 91]. Effective pre-acclimatization "at home" constitutes an attractive alternative to reduce onsite preparation and associated risks of exposure to mountain environments. It also can be tailored to individual responses to hypoxia and thus enables "precision pre-acclimatization". However, robust evidence for those effects, evidence-based guidelines for exposure strategies and clear safety recommendations, are largely lacking.

Therefore, this review is intended to summarize and interpret existing study findings on the physiology of highaltitude acclimatization and $\mathrm{HC}$ effects due to intermittent exposures to simulated altitudes (hypobaric or normobaric hypoxia), yielding a state-of-the-knowledge review on the use of simulated altitude exposure for pre-acclimatization.

\section{Methods}

Based on the literature search and personal experience, core studies and important observations have been selected to present a balanced view on the current knowledge of highaltitude illnesses and the acclimatization process, specifically focusing on pre-acclimatization strategies by $\mathrm{HC}$.

\section{Results and Discussion}

\section{The Physiology and Kinetics of Acclimatization to High Altitude/Hypoxia}

Acute exposure to both real altitude (hypobaric hypoxia) and simulated altitude (hypobaric and normobaric hypoxia) initiates similar physiological responses in order to counteract hypoxia and to improve oxygen delivery to tissues [71, 102, 104, 125]. The most relevant responses at a systemic level include hyperventilation, triggered by the hypoxic ventilatory response (HVR) [125], hemoconcentration due to diuresis [68], and the associated elevation of heart rate (HR) and cardiac output (CO) due to sympathetic activation [5, 83]. Changes of resting and exercising HRs are more variable than those of ventilation. Generally, HRs increase during acute hypoxia exposure and then decrease during about 1 week of acclimatization close to baseline, depending on the altitude and physical activity performed during the altitude exposure [42]. Owing to the direct vasodilating effect of hypoxia, blood pressure is maintained or even reduced when acutely exposed to hypoxia/high altitude. However, an elevated sympathetic drive during the following days/ weeks, causes an increase in blood pressure (during rest and exercise) associated with vasoconstriction, increased HR and CO [17]. The resting ventilation progressively increases during the first few days at high altitude, and levels off after 4-8 days until an altitude of about 4300 m [15,
101]. This result in partially restored alveolar oxygen partial pressure $\left(\mathrm{P}_{\mathrm{A}} \mathrm{O}_{2}\right)$ and reduced alveolar partial pressure of carbon dioxide $\left(\mathrm{P}_{\mathrm{A}} \mathrm{CO}_{2}\right)$ [72]. Consequently, the arterial partial pressure of oxygen $\left(\mathrm{P}_{\mathrm{a}} \mathrm{O}_{2}\right)$ and arterial oxygen saturation $\left(\mathrm{SaO}_{2}\right)$ improve (as compared to the initial impairment, but still remain below normoxic conditions) and the arterial partial pressure of carbon dioxide $\left(\mathrm{P}_{\mathrm{a}} \mathrm{CO}_{2}\right)$ decreases. The respiratory alkalosis (with hypocapnia) is at least partly compensated through the renal excretion of bicarbonate [130]. Characteristically, cerebral blood flow, which is primarily regulated by hypoxic vasodilation and hypocapnic/ hypercapnic vasoconstriction/vasodilation, increases during the first $12 \mathrm{~h}$ of high altitude exposure and subsequently declines with acclimatization (within 3-5 days) to near baseline values [2]. The increase of the cerebral blood flow is closely matched to the reduction in arterial oxygen content $\left(\mathrm{CaO}_{2}\right)$ in order to maintain cerebral oxygen delivery during acclimatization [2]. Another hallmark of hypoxia exposure is hypoxia pulmonary vasoconstriction (HPV) and increased pulmonary arterial pressure [6]. Since the critical $\mathrm{PO}_{2}$ that initiates HPV depends on the $\mathrm{P}_{\mathrm{A}} \mathrm{O}_{2}$ [116], some improvement may occur with acclimatization [90]. As true for most of the presented physiological responses to acute hypoxia and subsequent changes with acclimatization, this has also been highlighted for the HPV [45]. Schematic time courses of physiological responses during acclimatization to hypoxia (altitude) are depicted in Fig. 1.

A variety of physiological responses to hypoxia with different time courses occur at the cellular level, mediated primarily via reactive oxygen species (ROS) [113] and the activation of transcription factors including hypoxia-inducible factors (HIF) [109]. HIFs promote the expression of several hundreds of genes to maintain tissue oxygen supply. For instance, stabilization of the oxygen-regulated $\alpha$-subunit (HIF-1 $\alpha$ or its isoform HIF- $2 \alpha$ ) in hypoxia/at altitude effects the up-regulation of erythropoietin (EPO) and vascular endothelial growth factor (VEGF) transcription, promoting erythropoiesis and angiogenesis [58, 124]. Moreover, HIFs are also involved in the increase of glycolytic metabolism and the decrease of mitochondrial oxygen consumption in hypoxia [119]. Mitochondria consume the greatest portion of oxygen on the cellular level and are the main suppliers of cellular energy in the form of adenosine triphosphate (ATP) in many cell types. Hypoxia acutely induces the upregulation of glycolytic enzymes and glucose transporters, as well as a remodeling of the mitochondrial oxidative phosphorylation system to shift cellular energy metabolism more towards glycolysis [70]. Oxidative phosphorylation is modulated in response to hypoxia at several locations [69]. The upregulation of the inhibitor of respiratory complex I, NADH dehydrogenase [ubiquinone] $1 \alpha$ subcomplex 4-like 2 [120] or the induction of hypoxia-activated microRNAs like miR-210, which inhibit the synthesis of important electron transport 
Fig. 1 Schematic time courses of various physiological responses to acute hypoxia (altitude) exposure and during acclimatization $[2,5,10,37,71$, $83,94,102,125]$

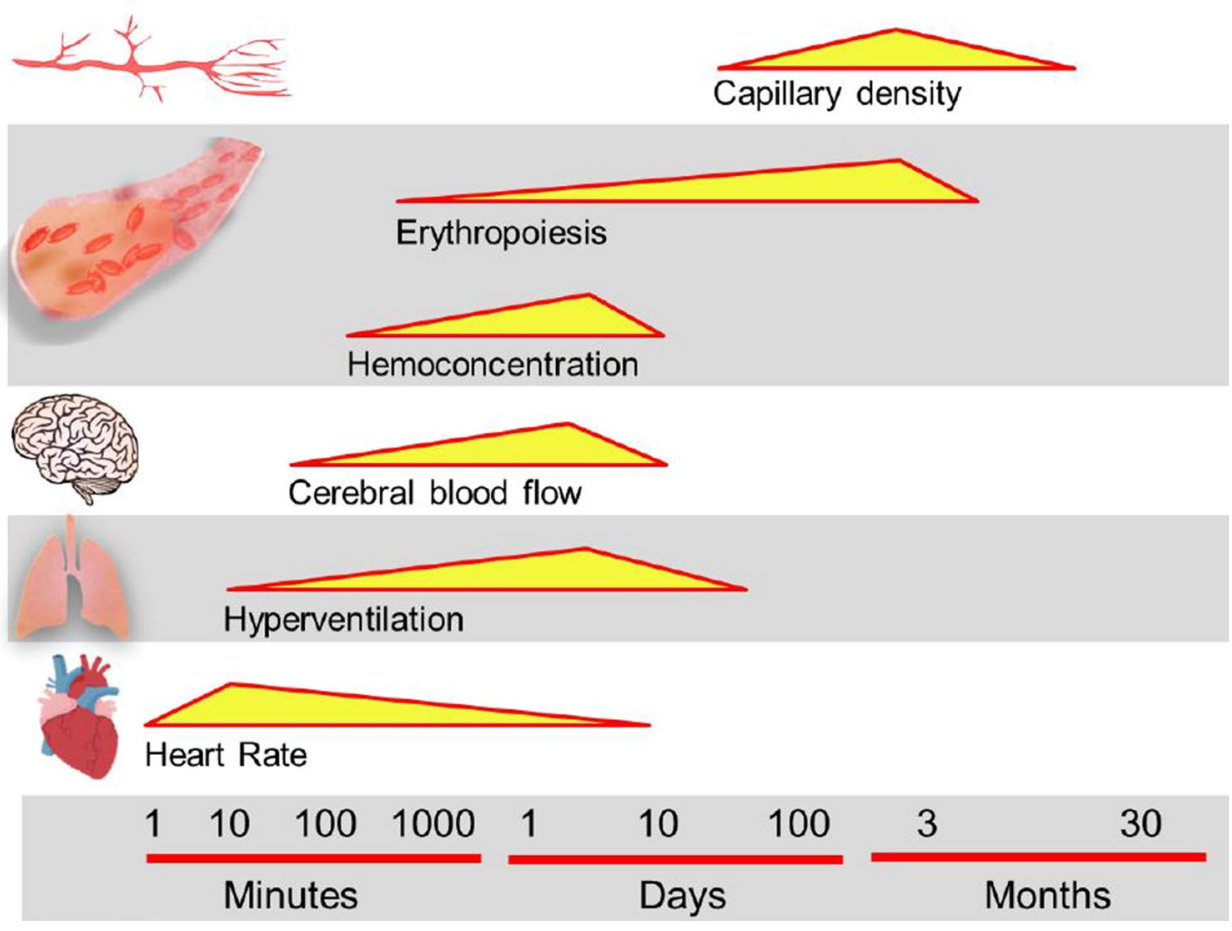

system components [31, 32, 93] are examples of reducing oxygen consumption. Hypoxia-related changes of respiratory complex IV may serve to increase oxygen utilization efficiency. In hypoxic conditions the complex IV subunit COX4I1 has been reported to be degraded and substituted by the COX4I2 isoform which increases efficiency of electron transfer from complex IV to $\mathrm{O}_{2}$ [47]. Similarly, the hypoxiainducible gene domain family member $1 \mathrm{~A}$ increases complex IV efficiency [60]. Such remodeling may be involved in long-term benefits of mitochondrial energy metabolism.

Plasma EPO concentration starts to increase during the first $2 \mathrm{~h}$ of hypoxia exposure and reaches a maximum within the first 2 days $(48 \mathrm{~h}$ ) but decreases subsequently, even if the hypoxic stimulus remains unchanged [123]. This time course of EPO concentration is paralleled by a decrease of the soluble form of the EPO receptor (sEPO$\mathrm{R}$, an endogenous antagonist of EPO) during the first $24 \mathrm{~h}$ at altitude/in hypoxia and subsequently remains at a reduced level, at least for $72 \mathrm{~h}$ [123]. The resulting EPO concentration is only slightly higher than sea level values, indicating that those minimally elevated EPO concentrations are sufficient to support erythropoiesis during chronic hypoxic conditions. Moreover, the hypoxia-stimulated production of red blood cells outweighs their degradation due to the long half life of red blood cells (about 3 months). Several further mechanisms contribute to the elevated erythropoiesis in chronic hypoxia, including upregulation of membrane EPO-R, antiapoptotic factors in erythroid progenitors in the bone marrow, and the reduced sEPO-R, which increases the free EPO concentration [76, 129]. A gradual increase of the hemoglobin mass (Hbmass) by $1 \%$ per $100 \mathrm{~h}$ spent at a sufficient level of hypoxia/altitude ( $>2000 \mathrm{~m}$ ) has been suggested, which seems to be independent of the altitude-exposure protocol (e.g., Live High Train High vs. Live High Train Low, see below) applied [53]. Finally, the erythropoietic response, e.g., to an altitude of $4550 \mathrm{~m}$ and associated increases in blood volume and red blood cells was demonstrated to slow down after about 3 months and to stabilize after about 8 months [94]. Finally, long-term exposure to hypoxia can induce the formation of new capillaries (angiogenesis), thereby supporting oxygen delivery to and aerobic metabolism of certain tissues, e.g., skeletal muscles [19]. HIF-dependent VEGF up-regulation plays a critical role for the increase in muscle capillarity and the generation of ROS, inflammatory cytokines and/or the change in the ratio of AMP/ATP are likely involved in this angiogenetic process as well [19]. Well-controlled animal (rats) experiments demonstrated an increase in the capillary-to-fiber $(\mathrm{C} / \mathrm{F})$ ratio only in relatively active, oxidative muscles (i.e., soleus and diaphragm) after a 3 -week hypoxia exposure (12\% oxygen) [36]. In a subsequent study, rats were exposed to hypoxia for 6 weeks, which resulted in angiogenesis in all studied muscles (also less active ones like the tibialis anterior) and a further increase of capillarity as compared to the 3-week hypoxia exposure [37]. The main systemic and cellular adaptations to hypoxia are summarized in Fig. 2. 

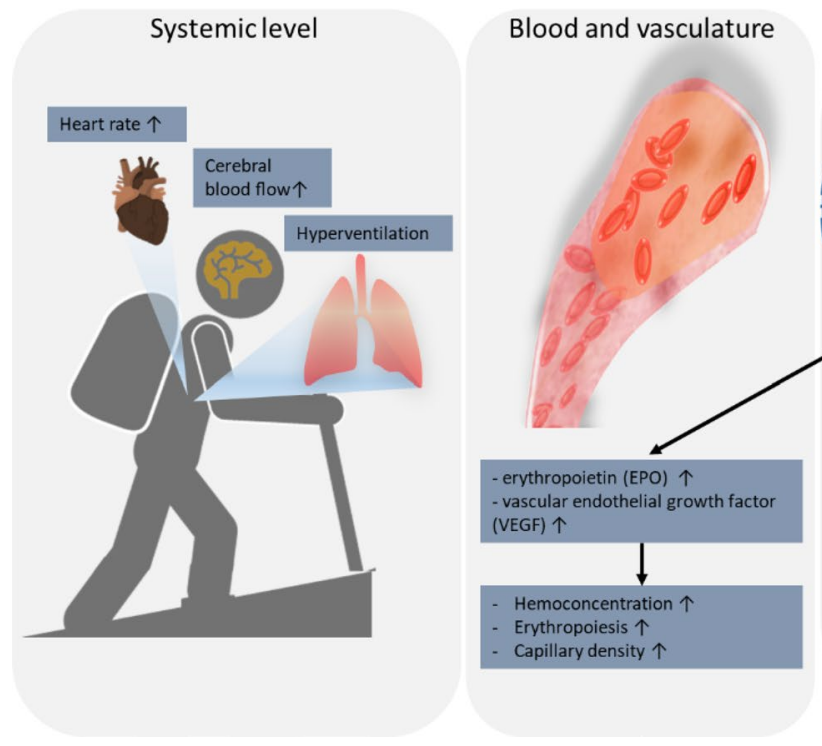

Fig. 2 Hypoxia adaptations: from the cellular to the systemic level. $R O S$ reactive oxygen species, HIFs hypoxia inducible factors, $N A D H$ nicotinamide adenine dinucleotide, $m i R$ microRNA, IMM inner mito-

\section{High-Altitude Illnesses}

Pre-acclimatization by $\mathrm{HC}$ is primarily intended to prevent high-altitude illnesses (HAI). Acute mountain sickness (AMS) and high-altitude cerebral edema (HACE) are cerebral forms of HAI because associated symptoms are primarily originating in the brain, e.g., headache [25]. While AMS is the most frequent HAI, usually benign and resolving after a few days at altitude, HACE develops rather rarely but represents a potentially life-threatening disease [25, 26, 91]. This is also true for high-altitude pulmonary edema, a pulmonary form of HAI, rarely developing below $3000 \mathrm{~m}$ but life-threatening if not treated immediately and appropriately [117].

The Lake Louise Scoring system (LLS) or the shortened (11-item) version (ESQ-C) of the 67-item Environmental Symptoms Questionnaire (ESQ-III) are frequently used diagnosis tools for AMS (M. [25, 26]. The LLS is a selfassessment questionnaire including five main symptoms (headache, nausea, dizziness, fatigue, and difficulty sleeping), each rated with a score from 0 to 3 ( 0 for no discomfort, 1 for mild, 2 for moderate, and 3 for severe symptoms). In the recently revised version of the LLS, "difficulty sleeping" has been eliminated as a questionnaire item [99]. AMS is defined as a score of 3 or higher, and the questions of the ESQ-C are scored on a scale of 0-5, with 0 reported as "not at all" and 5 as "extreme." Each response score is multiplied by the factorial weight of its symptom and a score of 0.70 or greater is classified as AMS-C.

Effects of $\mathrm{HC}$ are usually evaluated by monitoring of individual physiological responses, AMS development, and/or

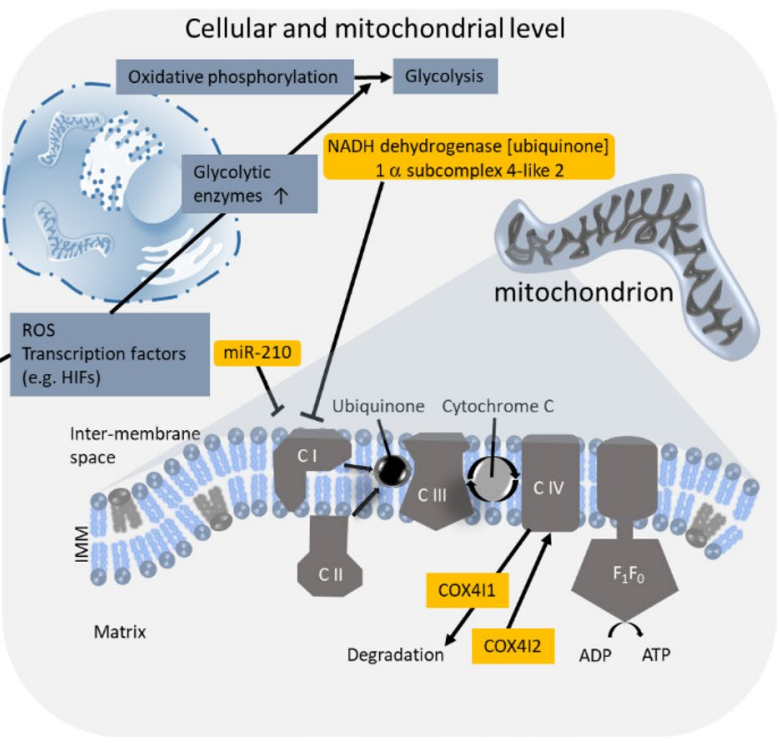

chondrial membrane, $C I-C I V$ complexes I to IV of the electron transport system, F1FO ATP synthase, COX4I1/COX4I2 components of complex IV (cytochrome c oxidase)

changes in exercise performance. Whereas aerobic exercise capacity (maximal oxygen consumption, $\mathrm{VO}_{2 \max }$ ) decreases with increasing altitude (related to the level of hypoxia) with a low impact of acclimatization, submaximal performance can be partially restored through acclimatization $[28,51]$.

\section{Traditional Acclimatization Strategies}

Beside pre-acclimatization at higher altitudes in relative proximity to individual locations of residence, e.g., mountainous areas of the Alps, the Rockies, etc., a slow and graded ascent is the most common strategy used to prevent illnesses related to high altitude (hypoxia) exposure. Although this is a long known and still practiced strategy, only a few studies assessed the effects of the ascent rate on high altitude illnesses in a controlled fashion [18]. It is a common rule, not to exceed a daily ascent rate of $500 \mathrm{~m}$ (refers to the sleeping elevation) at altitudes above $2500 \mathrm{~m}$ $[7,91]$. In addition, a resting day should be planned for every additional ascent of 1000-1500 m or in the case of health complaints. Recently, Richalet and colleagues provided a clinico-physiological score, derived from data of a multicenter study, for the identification of individuals susceptible to severe high altitude illness [98]. The authors defined an optimal ascent rate of $400 \mathrm{~m}$ per day ("400 m rule") and proposed a rational decision tree for the use of acetazolamide for the prevention of high-altitude illness. "Staging" represents a somewhat different acclimatization method and refers to the concept of staying at moderate altitudes of about 2000-3000 m for several days, which subsequently permits a more rapid ascent $[10,14]$. Both strategies, a slow ascent 
and staging, or a combination of both, have been traditionally used in trekking and high-altitude mountaineering and experiences from the field confirmed their effectiveness in high-altitude illness risk management but also to improve exercise performance $[10,14,50]$.

\section{Use and Effects of Intermittent Exposures to Simulated Altitude}

Simulated altitude (hypobaric or normobaric hypoxia) has been explored in research since decades and nowadays is used increasingly also for pre-acclimatization, therapeutic and preventive purposes $[4,16,55,63,97,103,118,122]$. Although the availability of hypobaric chambers is limited because costs and maintenance requirements are high, the use of normobaric hypoxia has become very popular owing to low cost and easy-to-use devices, e.g., generators and hypoxia breathing via face mask, hypoxia tents, or even hypoxia rooms for exercise and/or sleeping. Delving deeper into the complexity of differential hypoxia effects, in the following section we will shortly discuss potential differences between normobaric and hypobaric hypoxia effects, existing methods of hypoxia application, the use of intermittent hypoxia in therapy and prevention, and finally its use for pre-acclim(atiz)ation before going to real high altitudes. All types of hypoxia methods used for those purposes are subsequently termed $\mathrm{HC}$.

\section{Potential Differences Between Normobaric and Hypobaric Hypoxia}

While the reduction in ambient $\mathrm{PO}_{2}$ and subsequent hypoxemia are the strongest variable that trigger altitude-induced physiological responses (see above), several slight differences have been observed between adaptations to normobaric and hypobaric hypoxia, pointing to a specific influence of the barometric pressure. Preliminary results indicate a specific effect of hypobaria on responses to hypoxia, including differences in fluid balance [74]. Supporting these findings, Conkin and Wessel [34] highlighted influences of barometric pressure and criticized the "equivalent air altitude model". This model posits that altitude responses are exclusively induced by the alveolar oxygen pressure $\left(\mathrm{PAO}_{2}\right)$ decrease [33] and subsequently the magnitude of hypoxemia, without any influence of the barometric pressure. More recently, several research groups confirmed distinct effects of normobaric and hypobaric hypoxia, possibly influencing the effectiveness of the acclimatization. Although debated in the scientific literature [85, 96], it seems that hypobaric hypoxia is a more severe environmental condition than normobaric hypoxia [86] that accordingly induces more severe acute mountain sickness symptoms [39]. Amongst the variables that may have a particular impact on (pre-)acclimatization are differences in minute ventilation [104], in oxidative stress [43], or cerebrovascular function [1]. It was suggested that air density, hypoxic pulmonary vasoconstriction and circulating microbubbles may interact explaining higher resting ventilation in hypobaric than in normobaric hypoxia [75]. During exercise, the higher ventilatory response in hypobaric as compared to normobaric hypoxia is likely due to the lower flow resistance in the airways in hypobaria [92], but distinct breathing patterns (i.e., tidal volume and breathing frequency) may also contribute to those differences [104]. Moreover, it was reported that sleeping in hypobaric hypoxia leads to a larger desaturation and increased periodic breathing (i.e., more hypopnea and desaturation phases) [62] than sleeping in normobaric hypoxia. US army researchers have performed several studies to investigate the effectiveness of acclimatization in either normobaric and hypobaric hypoxia prior a stay at Pikes Peak (Colorado, $4300 \mathrm{~m}$ ) and several of these studies were summarized in a review [48] that enabled a robust comparison of distinct benefits and effectiveness of hypobaric versus normobaric hypoxia pre-acclimatization strategies. Since a larger ventilatory acclimatization and a lesser performance decrement was observed in hypobaric hypoxia than in normobaric hypoxia when the subjects were transported and assessed at Pikes Peak, these authors provided clear evidence of a better effectiveness of pre-acclimatization in hypobaric hypoxia. Moreover, the observed partial ventilatory acclimatization to normobaric hypoxia reported for the subjects, who were also pre-acclimatized in normobaric hypoxia, was not as effective as pre-acclimatization to hypobaric hypoxia and did not translate to lesser AMS or performance benefits [87]. Those findings indicate that pre-acclimatization in normobaric hypoxia could be optimized by a combination with exposure to hypobaric hypoxia. Indeed, this strategy-(i.e., living high-training low and high in normobaric hypoxia followed by few days in the Alps prior an expedition in the Himalayas) was successfully applied by an elite mountaineer on mount Everest [88].

\section{Different Hypoxia Methods Used in Athletes}

Historically, altitude training methods used by elite athletes emerged in the 1960s and were limited to the "Live HighTrain High" (LHTH) method for endurance athletes aiming to increase their oxygen transport. This "classical" method was complemented in the 1990s by the "Live High-Train Low" (LHTL) method, in which athletes benefit from the higher intensity of training possible at lower elevations, while residing at altitude [73]. In addition, innovative "Live Low-Train High" (LLTH) methods became popular. After 2000 , these three models were categorized as main altitude/ hypoxic training strategies [126, 127]. Recently, additional hypoxic methods have emerged, such as "Repeated-Sprint training in Hypoxia" (RSH) [54]. Nowadays, combinations 
of the different methods are used to maximize the benefits, while reducing main drawbacks of the distinct strategies,for example, by combining LHTL and RSH ("Live High-Train Low and High", LHTLH), where athletes "live high and train low except for few intense workouts in altitude" [89]. Additional benefits regarding both central aerobic fitness and peripheral muscular adaptations leading to improvement in repeated-sprint ability have been reported in teamsport players [20,21]. The most updated panorama of all the existing hypoxic/altitude training methods can be accessed in Girard et al. [54].

Regarding the acclimatization to high altitude, for a long time only methods similar to LHTH or LHTL (i.e. long exposure to increasing altitude levels and low-intensity exercise) have been prescribed to mountaineers [97]. We [88] reported that alternative methods are also effective. To our knowledge, to date, there is no study comparing the effectiveness of "traditional" acclimatization strategies like LHTH and "recent" strategies like LHTLH.

\section{Intermittent Hypoxia and Hypoxia-Hyperoxia Conditioning in Therapy and the Prevention of Various Diseases}

Generally, $\mathrm{HC}$ is defined as an exposure to systemic and/ or local hypoxia, resulting in insufficient oxygen supply to tissues, which is, in the case of systemic hypoxia, indicated by reduced $\mathrm{SaO}_{2}$ values [55], and can be applied passively or in combination with exercise for therapeutic and/or preventive purposes. If performed intermittently, reoxygenation between hypoxic intervals may be done in normoxia (intermittent hypoxia conditioning, IHC) or in hyperoxia (intermittent hypoxia-hyperoxia conditioning, IHHC) [8, 57]. These types of $\mathrm{HC}$ may also be applied to some extend to induce pre-acclimati(zati)on but also to monitor individual responses to hypoxia exposure in mountaineers.

Commonly applied IHC or IHHC programs utilize repeated exposures to normobaric hypoxia $\left(10 \%-16 \% \mathrm{O}_{2}\right)$ with a duration of 3-8 min, each interspersed by exposures to normoxic $\left(21 \% \mathrm{O}_{2}\right)(\mathrm{IHC})$ or hyperoxic $\left(30 \%-40 \% \mathrm{O}_{2}\right)$ (IHHC) gas for 2-5 min, resulting in a total duration of $30-40$ min per session $[8,57]$. Sessions are applied at 1 or 2-day intervals over $2-8$ weeks [8, 24, 27]. Gas mixtures are usually delivered via face masks, while peripheral oxygen saturation $\left(\mathrm{SpO}_{2}\right)$ and heart rate are continuously monitored by pulse-oximetry. IHC and more recently IHHC have been demonstrated to evoke beneficial health effects in patients suffering from various diseases, e.g., coronary artery disease [27], chronic obstructive pulmonary disease [24], systemic hypertension [78], metabolic disorders like diabetes [110], aging related decline in cognitive performance [107] and neurodegenerative diseases like Alzheimer's [8, 82] or Parkinson's disease [25, 26, 111].
$\mathrm{HC}$ in combination with exercise may also be performed as IHC or IHHC (previously also termed IHT or IHHT: intermittent hypoxia training and intermittent hypoxia-hyperoxia training, or using longer continuous sessions in normobaric hypoxia rooms. It has been suggested that $\mathrm{HC}$ with exercise might elicit synergistic effects of both stimuli, hypoxia and exercise, e.g., for the use of weight loss [65], the increase in bone density [29] and/or exercise tolerance [56, 115].

As outlined above, mechanisms responsible for hypoxia effects may be either related or unrelated to hypoxia-induced HIF activation as recently reviewed [69], and include improvements of stress resistance on the cellular and systemic level [27, 81], glucose homeostasis [41, 61] and blood lipid profile $[40,64,110]$, as well as the evocation of antiarrhythmic effects and improved autonomic cardiovascular and respiratory control $[27,59]$, and neuroprotection by upregulating neuroprotectants like VEGF, EPO, antioxidants and nitric oxide (NO), and/or by suppressing apoptosis [66]. Regarding IHHC, reoxygenation, especially when performed under hyperoxic conditions, generates ROS, which may trigger redox-signaling cascades initiating adaptations that contribute to injury resistance, e.g., by membrane-stabilizing effects in the heart, brain, and liver [3, 105, 106, 113]. Although the multitude of signaling pathways involved in hypoxia adaptations and their interactions are far from being fully elucidated, they may not only be used for the benefit of different patient groups but also contribute to (pre-)acclimatization, improved exercise tolerance and training efficiency (demonstrated by Sazontova and colleagues $[105,106]$.

\section{Hypoxia Conditioning for Pre-acclimatization to High Altitude}

Pre-acclimatization before high altitude sojourns for trekking or expeditions is not a novel technique. For instance, mountaineers from the Alps prepared and pre-acclimatized already in the 1950s and $60 \mathrm{~s}$ at altitudes (up to $4810 \mathrm{~m}$ ) of the alpine regions before climbing in the extreme altitudes of the Himalayas. At that time, exposure to real altitude (hypobaric hypoxia) was the method of choice, but also the application of normobaric hypoxia for potential pre-acclimatization has been evaluated already more than 3 decades ago, even using a light-weight mobile device (the altitude-conditioning apparatus) [22]. In this study 12 young men were exposed to normobaric hypoxia (inspiratory oxygen concentration, $\mathrm{FiO}_{2}: 13.8 \%$, about $3400 \mathrm{~m}$ simulated altitude) for $80 \mathrm{~h}$ (10 days for $8 \mathrm{~h}$ per day)). Subsequently, the participants were exposed to a simulated altitude of $4500 \mathrm{~m}$ (hypobaric chamber) for 2 days to evaluate effects of pre-acclimatization on the development of AMS. Although the authors reported no significant preventive effect, based on effect size calculations, there actually was a beneficial effect of pre-acclimatization 
by repeated normobaric hypoxia exposures (AMS-C 1.60 vs. 2.61 in the experimental group vs. controls, effect size 0.7) [22]. From this study, not only optimal hypoxia levels and exposure duration, but also potential influences of normobaria vs. hypobaria remained unclear. In subsequent years/decades, numerous experiments were performed in order to clarify the effectiveness of normobaric and hypobaric hypoxia exposures on the prevention of AMS and the reduction of aerobic exercise performance [10-14, $30,35,46,49,95,108,121,128]$. Unfortunately, large variations of related studies regarding the hypoxia levels, exposure durations, differences in the use of normobaric or hypobaric hypoxia, and often considerable discrepancies of the simulated altitude of pre-acclimatization and the subsequent altitude exposure for the assessment of AMS development still do not allow a systematic evaluation of efficacy. Characteristics and effects of hypoxia conditioning studies on peripheral oxygen saturation, and/or aerobic exercise performance, and/or acute mountain sickness are summarized in Table 1. Although the findings are partly conflicting, the majority of experiments demonstrated some beneficial consequences on AMS development and/ or aerobic exercise performance and importantly, no clinically relevant adverse events associated with pre-acclimatization have been reported. Various possibilities to apply normobaric hypoxia for $\mathrm{HC}$ and changes in the HVR and the LLS when re-exposed to simulated hypoxia (4500 m) after $7 \mathrm{~h}$ of HC are shown in Fig. 3.

Table 1 Characteristics and effects of hypoxia conditioning on peripheral oxygen saturation, and/or exercise performance, and/or acute mountain sickness

\begin{tabular}{|c|c|c|c|c|c|c|c|c|}
\hline Reference & $\begin{array}{l}\text { No. of sub- } \\
\text { jects (m/f), } \\
\text { age, no. of } \\
\text { controls }\end{array}$ & $\begin{array}{l}\text { Altitude exposure: } \\
\text { normobaric, hypo- } \\
\text { baric (simulated, } \\
\text { real) }\end{array}$ & $\begin{array}{l}\text { Exposure time: } \\
\text { hours or min } \\
\text { per day, no. } \\
\text { of days (total } \\
\text { hours) }\end{array}$ & $\begin{array}{l}\text { Exposure } \\
\text { type: rest/ } \\
\text { exercise }\end{array}$ & $\begin{array}{l}\text { Re-exposure: } \\
\text { normobaric, } \\
\text { hypobaric } \\
\text { (simuated, } \\
\text { real) }\end{array}$ & $\begin{array}{l}\mathrm{SpO}_{2}(\%): \text { pre/ } \\
\text { post vs. control } \\
\text { (rest/exercise) }\end{array}$ & $\begin{array}{l}\text { Exercise } \\
\text { perfor- } \\
\text { mance: post/ } \\
\text { pre change } \\
(\%)\end{array}$ & $\begin{array}{l}\text { Acute moun- } \\
\text { tain sickness: } \\
\text { LLS, pre/ } \\
\text { post AMS } \\
\text { incidence }(\%) \\
\text { vs. control }\end{array}$ \\
\hline $\begin{array}{l}\text { Beidleman } \\
\text { et al. [11] }\end{array}$ & $\begin{array}{r}5(4 / 1) \\
23 \pm 2\end{array}$ & $\begin{array}{l}4300 \mathrm{~m} \text {, hypobaric } \\
\text { (simulated) }\end{array}$ & $4,15(60)$ & Rest+ex & $\begin{array}{l}4300 \mathrm{~m}, \\
\text { hypobaric } \\
\text { (simulated) }\end{array}$ & $\begin{array}{l}\text { 82/90 (rest) } \\
74 / 78 \text { (ex) }\end{array}$ & $\begin{array}{l}+18 \\
\left(\mathrm{VO}_{2 \max }\right) \\
+21(\text { time } \\
\text { trial })\end{array}$ & $\mathrm{n} / \mathrm{a}$ \\
\hline $\begin{array}{l}\text { Beidleman } \\
\text { et al. [12] }\end{array}$ & $\begin{array}{r}5(4 / 1) \\
23 \pm 2\end{array}$ & $\begin{array}{l}4300 \mathrm{~m} \text {, hypobaric } \\
\text { (simuated) }\end{array}$ & $4,15(60)$ & Rest+ex & $\begin{array}{l}4300 \mathrm{~m}, \\
\text { hypobaric } \\
\text { (simulated) }\end{array}$ & $82 / 90$ (rest) & $\mathrm{n} / \mathrm{a}$ & $\begin{array}{l}\text { LLS: } 4.2 \pm 0.9 \\
\text { vs. } 0.8 \pm 0.3 \\
\text { (s) }\end{array}$ \\
\hline $\begin{array}{l}\text { Beidleman } \\
\text { et al. [13] }\end{array}$ & $\begin{array}{c}10(8 / 2) \\
26 \pm 2\end{array}$ & $\begin{array}{l}4300 \mathrm{~m} \text {, hypobaric } \\
\text { (simulated) }\end{array}$ & $4,7(28)$ & Rest + ex & $\begin{array}{l}4300 \mathrm{~m}, \\
\text { hypobaric } \\
\text { (simulated) }\end{array}$ & $\begin{array}{l}\text { 83/86 (rest) } \\
75 / 79 \text { (ex) }\end{array}$ & $\begin{array}{l}+16(\text { time } \\
\text { trial })\end{array}$ & $\mathrm{n} / \mathrm{a}$ \\
\hline $\begin{array}{l}\text { Beidleman } \\
\text { et al. [10, } \\
14]\end{array}$ & $\begin{array}{l}11(11 / 0) \\
21 \pm 1 \\
6\end{array}$ & $\begin{array}{c}3000 \mathrm{~m}+4500 \mathrm{~m}, \\
\text { normobaric }\end{array}$ & $\begin{array}{c}170 \min , 7 \\
(14+6)\end{array}$ & Rest+ex & $\begin{array}{l}4300 \mathrm{~m}, \\
\text { hypobaric } \\
\text { (simulated) }\end{array}$ & $\begin{array}{l}60 \text { h delay: } \\
81 / 82 \text { (rest) } \\
73 / 73(\mathrm{ex})\end{array}$ & No change & $\mathrm{n} / \mathrm{a}$ \\
\hline $\begin{array}{l}\text { Faulhaber } \\
\text { et al. [46] }\end{array}$ & $\begin{array}{l}33(16 / 17), \\
38 \pm 12 \\
9\end{array}$ & $\begin{array}{l}4500 \mathrm{~m} \text {, normo- } \\
\text { baric }\end{array}$ & $1,7(7)$ & Rest & $\begin{array}{l}3650 \mathrm{~m}, \\
\text { hypobaric } \\
(\text { real })\end{array}$ & $\begin{array}{l}\text { Base- } \\
\text { line } / 3650 \mathrm{~m} \\
97 / 90 \text { (rest) }\end{array}$ & $\mathrm{n} / \mathrm{a}$ & $\begin{array}{l}\text { AMS inci- } \\
\text { dence: } 59 \text { vs. } \\
67(\mathrm{~ns})\end{array}$ \\
\hline $\begin{array}{l}\text { Dehnert } \\
\text { et al. [35] }\end{array}$ & $\begin{array}{l}73(73 / 0), \\
26.5, \\
38\end{array}$ & $\begin{array}{c}2500-3300 \mathrm{~m}, \\
\text { normobaric }\end{array}$ & $\sim 7,14(\sim 100)$ & Rest (sleep) & $\begin{array}{l}4500 \mathrm{~m} \text {, nor- } \\
\text { mobaric }\end{array}$ & $\begin{array}{l}\text { vs. control } \\
78.5 / 81.2 \text { (rest) }\end{array}$ & $\mathrm{n} / \mathrm{a}$ & $\begin{array}{l}\text { AMS inci- } \\
\text { dence: } 14 \text { vs. } \\
52(\mathrm{~s})\end{array}$ \\
\hline $\begin{array}{l}\text { Ricart et al. } \\
\text { [95] }\end{array}$ & $\begin{array}{l}9(4 / 5) \\
43 \pm 10\end{array}$ & $\begin{array}{l}5000 \mathrm{~m} \text {, hypobaric } \\
\text { (simulated) }\end{array}$ & $2,14(28)$ & Rest & $\begin{array}{l}5000 \mathrm{~m}, \\
\text { hypobaric } \\
\text { (simulated) }\end{array}$ & 65/72 (ex) & $\mathrm{n} / \mathrm{a}$ & $\mathrm{n} / \mathrm{a}$ \\
\hline $\begin{array}{l}\text { Schommer } \\
\text { et al. [108] }\end{array}$ & $\begin{array}{l}40(22 / 18) \\
33 \pm 7 \\
20\end{array}$ & $\begin{array}{c}2500-4500 \mathrm{~m}, \\
\text { normobaric }\end{array}$ & $\begin{array}{l}(70 \mathrm{~min}, \\
9)+(90 \mathrm{~min}, \\
\text { 4) }(16.5)\end{array}$ & Rest + ex & $\begin{array}{l}3611 \mathrm{~m}, \\
\text { hypobaric } \\
(\text { real })\end{array}$ & $\begin{array}{l}\text { vs. control } \\
86.4 / 84.3\end{array}$ & $\mathrm{n} / \mathrm{a}$ & $\begin{array}{l}\text { AMS inci- } \\
\text { dence: } 6 \text { vs. } \\
47 \text { (s) }\end{array}$ \\
\hline $\begin{array}{l}\text { Schommer } \\
\text { et al. [108] }\end{array}$ & $\begin{array}{c}40(22 / 18) \\
33 \pm 7\end{array}$ & $\begin{array}{c}2500-4500 \mathrm{~m}, \\
\text { normobaric }\end{array}$ & $\begin{array}{l}(70 \mathrm{~min}, \\
9)+(90 \mathrm{~min}, \\
\text { 4) }(16.5)\end{array}$ & Rest + ex & $\begin{array}{l}4559 \mathrm{~m}, \\
\text { hypobaric } \\
\text { (real) }\end{array}$ & $\begin{array}{l}\text { vs. control } \\
73.6 / 75.8\end{array}$ & $\mathrm{n} / \mathrm{a}$ & $\begin{array}{l}\text { AMS inci- } \\
\text { dence: } 60 \text { vs. } \\
70(\mathrm{~ns})\end{array}$ \\
\hline $\begin{array}{l}\text { Treml et al. } \\
\text { [121] }\end{array}$ & $\begin{array}{l}49(25 / 24), \\
24 \pm 3, \\
26\end{array}$ & $\begin{array}{l}4500 \mathrm{~m} \text {, normo- } \\
\text { baric }\end{array}$ & $1,7(7)$ & Rest & $\begin{array}{l}4500 \mathrm{~m} \text {, nor- } \\
\text { mobaric }\end{array}$ & $81 / 85$ (rest) & $\mathrm{n} / \mathrm{a}$ & $\begin{array}{l}\text { LLS: } 2.8 \text { vs. } \\
1.3(\mathrm{~s})\end{array}$ \\
\hline $\begin{array}{l}\text { Wille et al. } \\
\text { [128] }\end{array}$ & $\begin{array}{c}26(26 / 0), \\
26 \pm 4, \\
13\end{array}$ & $\begin{array}{l}4500 \mathrm{~m} \text {, normo- } \\
\text { baric }\end{array}$ & $1,7(7)$ & Rest & $\begin{array}{l}4500 \mathrm{~m} \text {, nor- } \\
\text { mobaric }\end{array}$ & $\begin{array}{l}\text { HVR: }+50 \% \\
\text { from baseline }\end{array}$ & $\mathrm{n} / \mathrm{a}$ & $\begin{array}{l}\text { AMS inci- } \\
\text { dence: } 54 \text { vs. } \\
69(\mathrm{~ns})\end{array}$ \\
\hline
\end{tabular}


Fig. 3 Various possibilities (room, tent, face mask) to apply normobaric hypoxia for hypoxia conditioning (HC)
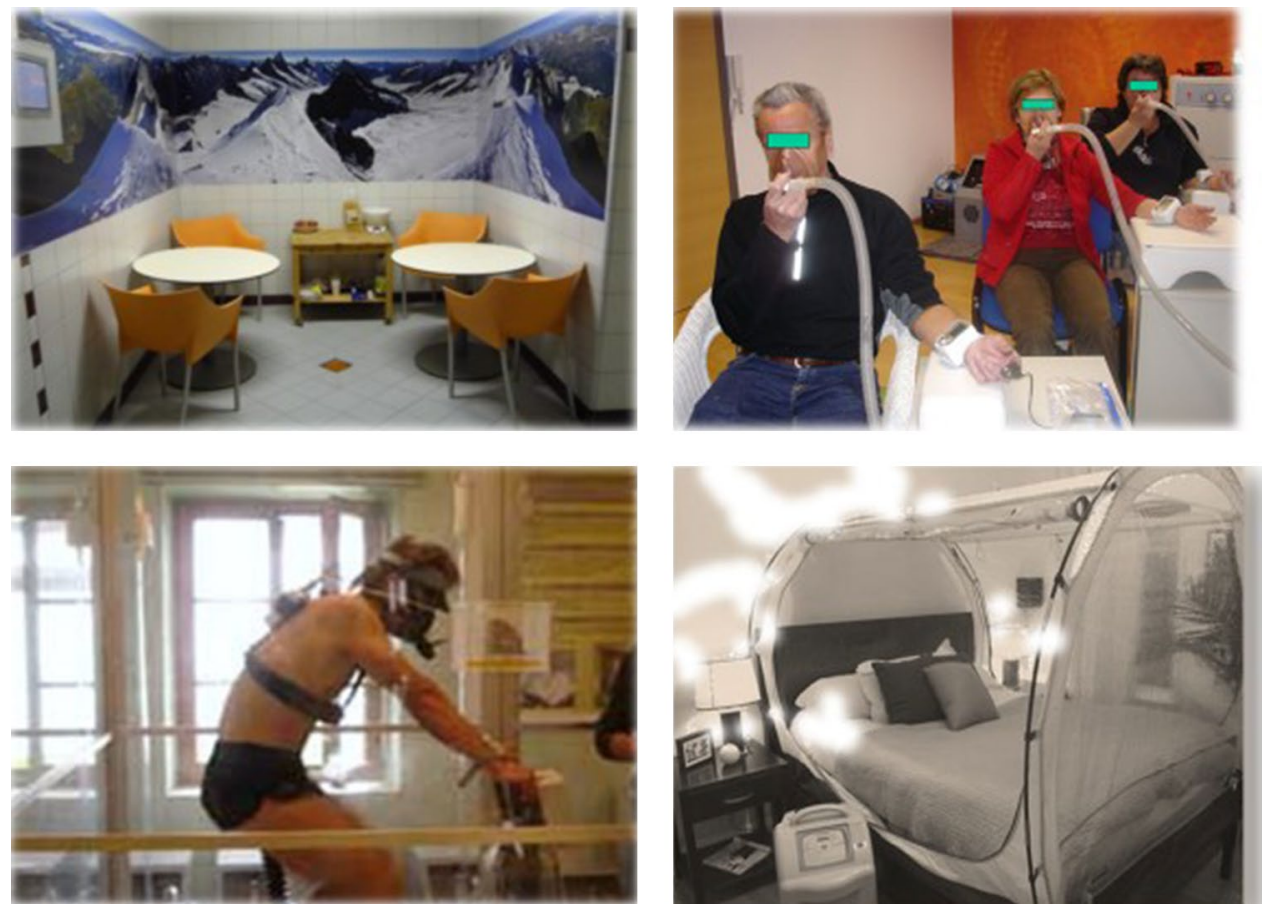

We previously summarized effects of repeated normobaric or hypobaric hypoxia exposures on ventilatory acclimatization, AMS development and/or aerobic exercise performance based on the findings of 21 studies [23]. The majority of studies reported some evidence of ventilatory acclimatization and HVR increase following HC. All studies evaluating AMS development and/or psychophysical performance after HC found beneficial effects, which occurred largely independently of the activity level (rest or exercise) during hypoxia exposure [23]. Exposure durations of 1-3 h per day for at least 1 week seem to be necessary for the induction of effective pre-acclimatization. The resulting benefits are thought to be preserved for about 1 week. Mostly, the hypoxia levels used were equivalent to about $4000 \mathrm{~m}\left(\mathrm{FiO}_{2}\right.$ of about $\left.12 \%\right)$. One study, in which the exposure to moderate hypoxia $\left(\mathrm{FiO}_{2}: 15.5 \%\right)$ did not cause HVR increase, suggests attenuated or no acclimatizing effects from such mild hypoxia protocols [67]. The majority of studies have been performed under resting conditions, but those directly comparing potential differences between rest and exercise in hypoxia did not see any differences $[11,12]$.

$\mathrm{HC}$ studies performed in hypobaric hypoxia (hypobaric chamber, 4000-5500 m) demonstrated a clear erythropoietic response to $3-5 \mathrm{~h}$ per day of hypoxia exposure over 9 days [100]. Another similar study with a 17-day hypoxia exposure (+ light aerobic exercise) confirmed the initiation of altitude acclimatization [30]. Ricart and colleagues exposed nine participants to a simulated altitude of $5000 \mathrm{~m}$ (hypobaric chamber) for $2 \mathrm{~h}$ per day for 14 days (total of $28 \mathrm{~h}$ ) [95] and found that during submaximal aerobic exercise in hypoxia $\mathrm{SpO}_{2}$ values rose from $65 \%$ to $71 \%$ and minute ventilation rose from 55.5 to $67.6 \mathrm{~L} /$ min [95]. Beidleman et al. exposed sea level residents for $4 \mathrm{~h}$ to hypobaric hypoxia (simulated altitude of $4300 \mathrm{~m}$ ) for 5 days/week over 3 weeks (total 60 h). Exercise testing in hypoxia pre- and post-intervention revealed a $21 \%$ improved aerobic exercise performance (cycling time trial) post-IHT [11], and a decrease of the AMS incidence from $50 \%$ pre-HC to $0 \%$ post-HC [12].

Beneficial $\mathrm{HC}$ effects have also been reported for normobaric hypoxia. For instance, Schommer and colleagues exposed 40 participants to normobaric hypoxia (simulating 2500, 3000, and $3500 \mathrm{~m}$ during 3 weeks + exercise) [108]. The participants exercised for $70 \mathrm{~min}$, three times per week at their individual $60 \% \mathrm{VO}_{2 \max }$ and additionally were passively exposed to hypoxia four times for 90-min in week 4 (total exposure time of $16.5 \mathrm{~h}$ ). Five days after completing the program, the participants ascended to $4559 \mathrm{~m}$ real altitude. While at $3611 \mathrm{~m}$, the AMS incidence was only $6 \%$ in $\mathrm{HC}$ subjects as compared to $47 \%$ in controls, AMS was not different between the groups at $4559 \mathrm{~m}$ [108]. From these findings it may be concluded that acclimation effects after $\mathrm{HC}$ are effective up to the altitude (hypoxia level) used during HC, but may not prevent from AMS when climbing much higher. This is also true for findings from another study, where 23 subjects slept seven nights for $7.5 \mathrm{~h}$ (total $52.5 \mathrm{~h})$ in normobaric hypoxia $\left(\mathrm{FiO}_{2}\right.$ decreasing to $14.4 \%$, $3100 \mathrm{~m}$ ) [49]. Subsequently, the participants ascended to $4300 \mathrm{~m}$ real altitude for 5 days. $\mathrm{SpO}_{2}$ during sleep at altitude was significantly higher in the HC group, $80 \%$ vs. $76 \%$ in the 
control group, and AMS was reduced (only) upon awakening in the $\mathrm{HC}$ group (AMS-C 0.34 vs. $0.83, P<0.02$ ).

A $\mathrm{HC}$ protocol exposing individuals to $12 \% \mathrm{FiO}_{2}$ for $4 \mathrm{~h}$ per day was suggested to promote acclimatization by attenuation of hypoxia-induced inflammation and dyslipidemia [52]. Exposure to high altitude after this type of IHT, resulted in significantly higher $\mathrm{SpO}_{2}$ values and lower AMS incidence as compared to controls and was associated with lower levels of acute-phase proteins like C-reactive protein (CRP), serum amyloid A-1 protein (SAA), and fibrinogen (FGA, FGB, and FGG) [52].

We recently demonstrated that even short hypoxia bouts $\left(1 \mathrm{~h}\right.$ at $\mathrm{FiO}_{2}$ of $\left.11 \%\right)$ for 7 consecutive days, effectively reduced the AMS incidence during hypoxia re-exposure 7 days after completing the HC program $(87 \%$ showed a lower LLS in the IH vs. 50\% in the control group) [121]. Subjects susceptible to high-altitude pulmonary edema (HAPE), who often have low HVR, may benefit from such short HC [23]. HAPE represents a non-cardiogenic pulmonary edema, which is provoked by exaggerated hypoxic pulmonary vasoconstriction and an increase in pulmonary artery and capillary pressure $[25,26]$.

Although both normobaric and hypobaric $\mathrm{HC}$ induce acclimatization, hypobaric $\mathrm{HC}$ might be somewhat more effective in the prevention of AMS, as it was shown that hypoxia, hypobaria and prolonged aerobic exercise were all independently predictive for the severity of AMS development [38]. Potential (patho-)physiological differences between normobaric and hypobaric hypoxia have recently been extensively discussed $[85,96]$. The importance of exhaustive exercise on the AMS incidence was demonstrated in epidemiological studies [80].

Effects of long pre-acclimatization protocols before going to very high altitudes $(>8000 \mathrm{~m}$ ) have very recently been reported [118]. The concept of long-duration HC (6-8 weeks) is based on successful case studies in expedition participants performed in our lab. Selected results of such a case study are depicted in Fig. 4. Participants of commercial expeditions, who rapidly (from home and back within 3 weeks) ascended Mt. Everest ( 8849 m), carried out 8 weeks of $\mathrm{HC}$, reaching sleeping altitudes equivalent to $7100 \mathrm{~m}$, and overall spent at least $300 \mathrm{~h}$ in hypoxia [118]. These participants tolerated the subsequent rapid ascend up to above $6000 \mathrm{~m}$ (without supplemental oxygen) well and successfully climbed Mt. Everest (with supplemental oxygen). It was also reported that an oxygen flow rate of $2 \mathrm{~L}$ per minute at rest was sufficient to keep the $\mathrm{PiO}_{2}$ close to $50 \mathrm{mmHg}$ even at the summit and that for heavy physical activity (climbing) $6 \mathrm{~L}$ of oxygen per minute are required to maintain that $\mathrm{PiO}_{2}$ [118].

As these findings are preliminary and sometimes even controversial, largely based on uncontrolled studies and case reports, future well-controlled experiments are needed

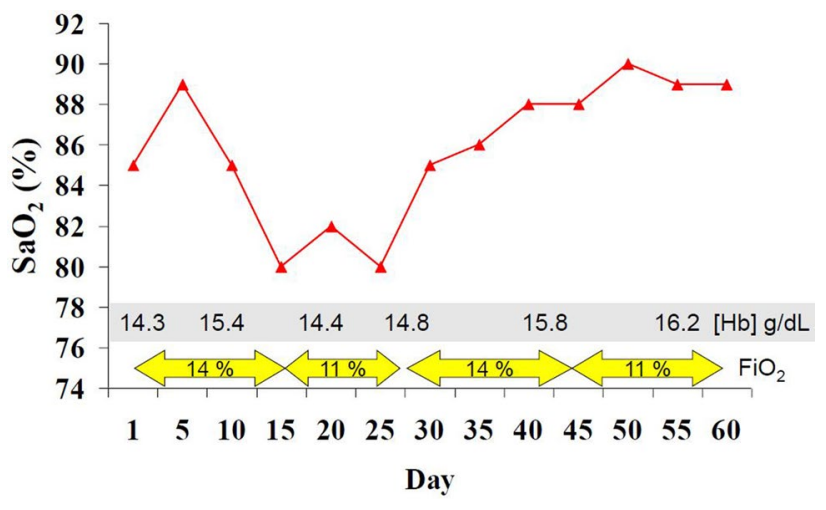

Fig. 4 Case study of long-term normobaric hypoxia conditioning. The mountaineer spent 60 nights (about $7 \mathrm{~h}$ per night; total about $420 \mathrm{~h}$ ) in a hypoxia tent. The time course of $\mathrm{SaO}_{2}$ values indicates that some individual adjustments of the inspiratory oxygen concentration $\left(\mathrm{FiO}_{2}\right)$ will be necessary to prevent adverse effects and to promote optimal ventilatory acclimatization. Hemoglobin concentration [Hb] rose initially (hemoconcentration) then decreased to baseline and started to increased again (after about 20 nights) likely as a consequence of erythropoiesis

including a broad range of age categories of both sexes, using different hypoxia-exposure protocols and proper evaluation of pre-acclimation effects when subsequently exposed to real altitude.

\section{How Long are (Pre-)acclimatization Effects Retained?}

Finally, the question arises for how long (pre-)acclimatization effects can be retained to attenuate AMS development upon re-exposure to high altitude. This question has been addressed by Lyons and colleagues, who re-exposed 6 male lowlanders to high altitude $(4300 \mathrm{~m}$ in a hypobaric chamber) after an 8-day stay at sea level following a 16-day acclimatization period at $4300 \mathrm{~m}$ at real altitude [79]. When compared with the first day at real high altitude (4300 m), mean AMS-C scores were significantly reduced from 0.6 to 0.1 during re-exposure, and only one person got sick when re-exposed as compared to four subjects at the initial exposure to real altitude. Retained acclimatization was also confirmed by elevated $\mathrm{SpO}_{2}$, hemoglobin and hematocrit values during re-exposure [79]. In another study, effects of prior acclimatization $(5260 \mathrm{~m})$ on the cerebrovascular and ventilatory responsiveness to carbon dioxide have been assessed in 21 individuals during reexposure after 7 and 21 days following a 7 -day stay at low altitude $(1500 \mathrm{~m})$ [44]. These authors demonstrated that the enhanced ventilatory $\mathrm{CO}_{2}$ response was partly retained only after 7 days at low altitude. The molecular basis of faster acclimatization upon re-ascent to high altitude may 


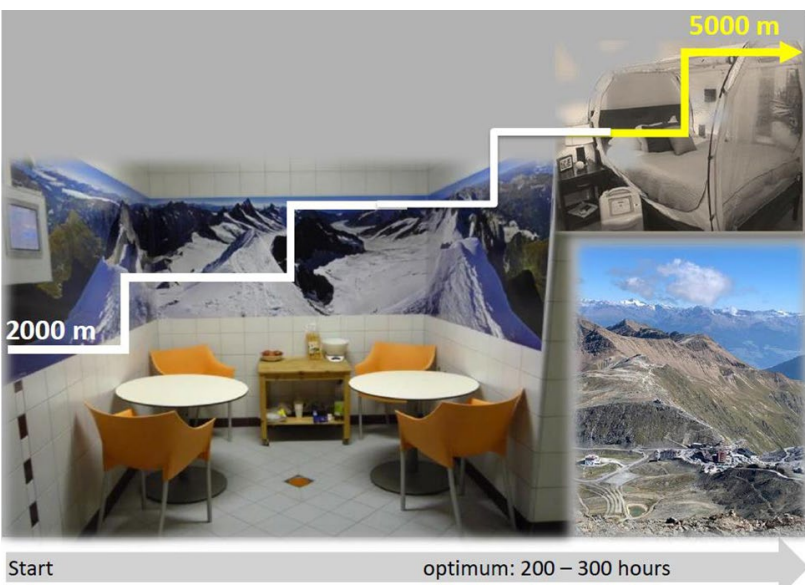

Fig. 5 Schematic presentation of recommendations about hypoxia conditioning/pre-acclimatization in normobaric (complemented by hypobaric) hypoxia. Hypoxia severity in (simulated) altitude will progressively increase (from about 2000-5000 m) during the total exposure time (intermittent exposures during day and especially night time; with and without exercise) of about $200-300 \mathrm{~h}$

include the induction of higher plasma adenosine levels during re-ascent as a consequence of erythrocyte hypoxic memory [114].

In another study, out of 17 young sea level residents, $88 \%$ developed AMS (using the LLQ criteria) during the initial high-altitude exposure $(4300 \mathrm{~m})$, which declined to $0 \%$ during the 12-day acclimatization period [9]. Upon re-exposure to a simulated altitude of $4300 \mathrm{~m}$ (hypobaric chamber) after a 12-day stay at sea level, only $17 \%$ developed AMS, indicating that a large acclimatization effect was retained. Interestingly, normobaric hypoxia exposure ( $3 \mathrm{~h}$ per day during the sea level stay) did not further reduce AMS development [9]. These findings, however, rather demonstrate a prolonged (12 days) effectiveness of prior acclimatization rather than corroborating ineffectiveness of normobaric hypoxia for pre-acclimatization.

It may be concluded that in certain cases even short periods (e.g., $7 \mathrm{~h}$ ) of pre-acclimatization by $\mathrm{HC}$ are effective, but longer periods (e.g., $>60 \mathrm{~h}$ ) are needed to elicit more robust effects. Based on case observations and time courses of various physiological responses to acute hypoxia (Fig. 1), about $300 \mathrm{~h}$ of HC (intermittently applied) may yield optimal acclimatization effects for extreme altitude exposures [118], but every hour spent in hypoxia may add further benefits. If possible, the inclusion of hypobaric exposures (i.e., sojourns to real altitude, including overnight stays) into preacclimatization protocols seems to be useful to increase the efficiency. The level of simulated altitude is usually progressively increased or adjusted (depending on the individual tolerability) and should reach the hypoxia level of the initial sleeping altitude of the trekking or expedition event (Fig. 5).
HC should not be stopped earlier than 1-2 weeks before the altitude sojourn. As both the tolerance to altitude/hypoxia and the time course of acclimati(zati)on differ largely between individuals, proper medical monitoring is needed. This includes periodical recordings of $\mathrm{SpO}_{2}$, HR and blood pressure changes during day and night time, individual wellbeing/complaints (AMS scoring), sleep quality and quantity. Moreover, conditions in the hypoxia tent/room, i.e., $\mathrm{PiO}_{2}$, $\mathrm{PiCO}_{2}$, temperature, and humidity need to be closely monitored, triggering an alarm when certain limits are exceeded.

Comprehensive future studies evaluating individual responses to various pre-acclimatization strategies including effects of age, sex, exercise, diet, and sleep are required to increase our understanding of HC. This has also recently been pointed out by an opinion position by members of the Union Internationale des Associations d'Alpinisme Medical Commission (UIAA MedCom). The authors conclude that exposures to intermittent normobaric hypoxia (i.e., HC) prior to high-altitude climbing may reduce AMS symptoms and enhance the chance to succeed in high-altitude expeditions [63], but robust evidence for those effects are still lacking and particular attention has to be paid to safety issues.

A large heterogeneity of conditions and the (mostly) lacking evaluation of $\mathrm{HC}$ effects at subsequent real high-altitude exposure of available studies, currently impede a clear definition of optimal parameters for optimum pre-acclimatization. Further, great differences in individual capacities to tolerate and adapt to hypoxia highlight the need for individually tailored $\mathrm{HC}$. The application of a broad range of (intermittent) $\mathrm{HC}$ exposure times (up to $300 \mathrm{~h}$ ), as well as the inclusion of both sexes of various age ranges in future studies and the comparison of physiological responses during $\mathrm{HC}$ and associated effects during the subsequent real altitude exposure have the potential to greatly advance the field. Moreover, possible benefits of adding various periods of real (hypobaric) altitude exposures to normobaric HC need to be evaluated.

\section{Conclusions}

Taken together, HC has great potential not only to conveniently be applied as a pre-acclimatization strategy before high altitude exposure but also may be highly effective as a treatment strategy for a variety of diseases apart from HAIs and to improve aerobic exercise performance. The lack of clear guidelines for $\mathrm{HC}$ and conclusive results demonstrating $\mathrm{HC}$ robustness, however, indicate that this research field is still in its infancy and will massively benefit from systematic evaluations not only of the effects of hypoxia parameters (including duration, frequency and severity) but also on the responsiveness of different target groups, including athletes and patients suffering from various diseases. 
Author Contributions Conceptualization (MB and JB), literature search/selection (MB, JB, GPM), writing and proof reading (MB, JB, GPM).

Funding Open access funding provided by University of Innsbruck and Medical University of Innsbruck. There is no funding to be reported.

Availability of Data and Material Not applicable.

Code Availability Not applicable.

\section{Declarations}

Conflicts of Interest The authors declare no conflicts of interest.

Ethics approval Not applicable.

Consent to participate Not applicable.

Consent to publish Not applicable.

Open Access This article is licensed under a Creative Commons Attribution 4.0 International License, which permits use, sharing, adaptation, distribution and reproduction in any medium or format, as long as you give appropriate credit to the original author(s) and the source, provide a link to the Creative Commons licence, and indicate if changes were made. The images or other third party material in this article are included in the article's Creative Commons licence, unless indicated otherwise in a credit line to the material. If material is not included in the article's Creative Commons licence and your intended use is not permitted by statutory regulation or exceeds the permitted use, you will need to obtain permission directly from the copyright holder. To view a copy of this licence, visit http://creativecommons.org/licenses/by/4.0/.

\section{References}

1. Aebi MR, Bourdillon N, Kunz A, Bron D, Millet GP. Specific effect of hypobaria on cerebrovascular hypercapnic responses in hypoxia. Physiol Rep. 2020;8(4): e14372. https://doi.org/10. 14814/phy2.14372.

2. Ainslie PN, Subudhi AW. Cerebral blood flow at high altitude. High Alt Med Biol. 2014;15(2):133-40. https://doi.org/10.1089/ ham.2013.1138.

3. Arkhipenko YV, Sazontova TG, Zhukova AG. Adaptation to periodic hypoxia and hyperoxia improves resistance of membrane structures in heart, liver, and brain. Bull Exp Biol Med. 2005;140(3):278-81.

4. Baillieul S, Chacaroun S, Doutreleau S, Detante O, Pépin JL, Verges S. Hypoxic conditioning and the central nervous system: a new therapeutic opportunity for brain and spinal cord injuries? Exp Biol Med (maywood, NJ). 2017;242(11):1198-206. https:// doi.org/10.1177/1535370217712691.

5. Bärtsch P, Gibbs JS. Effect of altitude on the heart and the lungs. Circulation. 2007;116(19):2191-202. https://doi.org/10.1161/ CIRCULATIONAHA.106.650796.

6. Bärtsch P, Maggiorini M, Ritter M, Noti C, Vock P, Oelz O. Prevention of high-altitude pulmonary edema by nifedipine. N Engl J Med. 1991;325(18):1284-9. https://doi.org/10.1056/ NEJM199110313251805.
7. Bärtsch $P$, Swenson ER. Clinical practice: acute high-altitude illnesses. N Engl J Med. 2013;368(24):2294-302. https://doi. org/10.1056/NEJMcp1214870.

8. Bayer U, Likar R, Pinter G, Stettner H, Demschar S, Trummer B, Burtscher M. Intermittent hypoxic-hyperoxic training on cognitive performance in geriatric patients. Alzheimers Dement (N Y). 2017;3(1):114-22. https://doi.org/10.1016/j.trci.2017.01.002.

9. Beidleman BA, Fulco CS, Cadarette BS, Cymerman A, Buller MJ, Salgado RM, Muza SR. Is normobaric hypoxia an effective treatment for sustaining previously acquired altitude acclimatization? J Appl Physiol (1985). 2017;123(5):1214-27. https:// doi.org/10.1152/japplphysiol.00344.2017.

10. Beidleman BA, Fulco CS, Muza SR, Rock PB, Staab JE, Forte VA, Cymerman A. Effect of six days of staging on physiologic adjustments and acute mountain sickness during ascent to 4300 meters. High Alt Med Biol. 2009a;10(3):253-60. https://doi. org/10.1089/ham.2009.1004.

11. Beidleman BA, Muza SR, Fulco CS, Cymerman A, Ditzler DT, Stulz D, Sawka MN. Intermittent altitude exposures improve muscular performance at 4,300 m. J Appl Physiol (1985). 2003;95(5):1824-32. https://doi.org/10.1152/japplphysiol. 01160.2002 .

12. Beidleman BA, Muza SR, Fulco CS, Cymerman A, Ditzler D, Stulz D, Sawka MN. Intermittent altitude exposures reduce acute mountain sickness at $4300 \mathrm{~m}$. Clin Sci (lond). 2004;106(3):321-8. https://doi.org/10.1042/CS20030161.

13. Beidleman BA, Muza SR, Fulco CS, Cymerman A, Sawka MN, Lewis SF, Skrinar GS. Seven intermittent exposures to altitude improves exercise performance at $4300 \mathrm{~m}$. Med Sci Sports Exerc. 2008;40(1):141-8. https://doi.org/10.1249/mss. 0b013e31815a519b.

14. Beidleman BA, Muza SR, Fulco CS, Jones JE, Lammi E, Staab JE, Cymerman A. Intermittent hypoxic exposure does not improve endurance performance at altitude. Med Sci Sports Exerc. 2009b;41(6):1317-25. https://doi.org/10.1249/MSS. 0b013e3181954601.

15. Bender PR, McCullough RE, McCullough RG, Huang SY, Wagner PD, Cymerman A, Reeves JT. Increased exercise SaO2 independent of ventilatory acclimatization at 4,300 m. J Appl Physiol (1985). 1989;66(6):2733-8. https://doi.org/10.1152/ jappl.1989.66.6.2733.

16. Benoit H, Germain M, Barthelemy JC, Denis C, Castells J, Dormois D, Geyssant A. Pre-acclimatization to high altitude using exercise with normobaric hypoxic gas mixtures. Int $\mathbf{J}$ Sports Med. 1992;13(Suppl 1):S213-216. https://doi.org/10. 1055/s-2007-1024643.

17. Bilo G, Caravita S, Torlasco C, Parati G. Blood pressure at high altitude: physiology and clinical implications. Kardiol Pol. 2019;77(6):596-603. https://doi.org/10.33963/KP.14832.

18. Bloch KE, Turk AJ, Maggiorini M, Hess T, Merz T, Bosch MM, Schoch OD. Effect of ascent protocol on acute mountain sickness and success at Muztagh Ata, 7546 m. High Alt Med Biol. 2009;10(1):25-32. https://doi.org/10.1089/ham.2008. 1043.

19. Breen E, Tang K, Olfert M, Knapp A, Wagner P. Skeletal muscle capillarity during hypoxia: VEGF and its activation. High Alt Med Biol. 2008;9(2):158-66. https://doi.org/10.1089/ham.2008. 1010.

20. Brocherie F, Millet GP, D'Hulst G, Van Thienen R, Deldicque L, Girard O. Repeated maximal-intensity hypoxic exercise superimposed to hypoxic residence boosts skeletal muscle transcriptional responses in elite team-sport athletes. Acta Physiol (oxf). 2018;222(1):e12851. https://doi.org/10.1111/apha.12851.

21. Brocherie F, Millet GP, Hauser A, Steiner T, Rysman J, Wehrlin JP, Girard O. "Live high-train low and high" hypoxic training improves team-sport performance. Med Sci Sports Exerc. 
2015;47(10):2140-9. https://doi.org/10.1249/MSS.0000000000 000630 .

22. Burse RL, Forte VA. Acute mountain sickness at $4500 \mathrm{~m}$ is not altered by repeated eight-hour exposures to 3200-3550 m normobaric hypoxic equivalent. Aviat Space Environ Med. 1988;59(10):942-9.

23. Burtscher M, Brandstatter E, Gatterer H. Preacclimatization in simulated altitudes. Sleep Breath. 2008;12(2):109-14. https:// doi.org/10.1007/s11325-007-0127-9.

24. Burtscher M, Haider T, Domej W, Linser T, Gatterer H, Faulhaber M, Bernardi L. Intermittent hypoxia increases exercise tolerance in patients at risk for or with mild COPD. Respir Physiol Neurobiol. 2009;165(1):97-103. https://doi.org/10.1016/j.resp. 2008.10.012.

25. Burtscher M, Hefti U, Hefti JP. High-altitude illnesses: Old stories and new insights into the pathophysiology, treatment and prevention. Sports Med Health Sci. 2021b;3(2):59-69. https:// doi.org/10.1016/j.smhs.2021.04.001.

26. Burtscher J, Mallet RT, Burtscher M, Millet GP. Hypoxia and brain aging: neurodegeneration or neuroprotection? Ageing Res Rev. 2021a;68: 101343. https://doi.org/10.1016/j.arr.2021. 101343.

27. Burtscher M, Pachinger O, Ehrenbourg I, Mitterbauer G, Faulhaber M, Pühringer R, Tkatchouk E. Intermittent hypoxia increases exercise tolerance in elderly men with and without coronary artery disease. Int J Cardiol. 2004;96(2):247-54. https:// doi.org/10.1016/j.ijcard.2003.07.021.

28. Calbet JA, Boushel R, Radegran G, Sondergaard H, Wagner $\mathrm{PD}$, Saltin B. Why is VO2 max after altitude acclimatization still reduced despite normalization of arterial $\mathrm{O} 2$ content? Am J Physiol Regul Integr Comp Physiol. 2003;284(2):R304-316. https://doi.org/10.1152/ajpregu.00156.2002.

29. Camacho-Cardenosa M, Camacho-Cardenosa A, Timón R, Olcina G, Tomas-Carus P, Brazo-Sayavera J. Can hypoxic conditioning improve bone metabolism? A systematic review. Int J Environ Res Public Health. 2019;16(10):1799. https://doi.org/ 10.3390/ijerph16101799.

30. Casas M, Casas H, Pagés T, Rama R, Ricart A, Ventura JL, Viscor G. Intermittent hypobaric hypoxia induces altitude acclimation and improves the lactate threshold. Aviat Space Environ Med. 2000;71(2):125-30.

31. Chan SY, Zhang Y-Y, Hemann C, Mahoney CE, Zweier JL, Loscalzo J. MicroRNA-210 controls mitochondrial metabolism during hypoxia by repressing the iron-sulfur cluster assembly proteins ISCU1/2. Cell Metab. 2009;10(4):273-84.

32. Chen Z, Li Y, Zhang H, Huang P, Luthra R. Hypoxia-regulated microRNA-210 modulates mitochondrial function and decreases ISCU and COX10 expression. Oncogene. 2010;29(30):4362-8.

33. Conkin J. Equivalent air altitude and the alveolar gas equation. Aerosp Med Hum Perform. 2016;87(1):61-4. https://doi.org/10. 3357/AMHP.4421.2016.

34. Conkin J, Wessel JH. Critique of the equivalent air altitude model. Aviat Space Environ Med. 2008;79(10):975-82. https:// doi.org/10.3357/asem.2331.2008.

35. Dehnert C, Bohm A, Grigoriev I, Menold E, Bartsch P. Sleeping in moderate hypoxia at home for prevention of acute mountain sickness (AMS): a placebo-controlled, randomized double-blind study. Wilderness Environ Med. 2014;25(3):263-71. https://doi. org/10.1016/j.wem.2014.04.004.

36. Deveci D, Marshall JM, Egginton S. Relationship between capillary angiogenesis, fiber type, and fiber size in chronic systemic hypoxia. Am J Physiol Heart Circ Physiol. 2001;281(1):H241252. https://doi.org/10.1152/ajpheart.2001.281.1.H241.
37. Deveci D, Marshall JM, Egginton S. Chronic hypoxia induces prolonged angiogenesis in skeletal muscles of rat. Exp Physiol. 2002;87(3):287-91. https://doi.org/10.1113/eph8702377.

38. DiPasquale DM, Strangman GE, Harris NS, Muza SR. Hypoxia, hypobaria, and exercise duration affect acute mountain sickness. Aerosp Med Hum Perform. 2015;86(7):614-9. https://doi.org/10. 3357/AMHP.4266.2015.

39. DiPasquale DM, Strangman GE, Harris NS, Muza SR. Acute mountain sickness symptoms depend on normobaric versus hypobaric hypoxia. Biomed Res Int. 2016;2016:6245609. https:// doi.org/10.1155/2016/6245609.

40. Du X, Girard O, Fan RY, Ma F. Effects of active and passive hypoxic conditioning for 6 weeks at different altitudes on blood lipids, leptin, and weight in rats. High Alt Med Biol. 2020;21(3):243-8. https://doi.org/10.1089/ham.2020.0003.

41. Duennwald T, Gatterer H, Groop PH, Burtscher M, Bernardi L. Effects of a single bout of interval hypoxia on cardiorespiratory control and blood glucose in patients with type 2 diabetes. Diabetes Care. 2013;36(8):2183-9. https://doi.org/10.2337/dc12-2113.

42. Dünnwald T, Kienast R, Niederseer D, Burtscher M. The use of pulse oximetry in the assessment of acclimatization to high altitude. Sensors (basel). 2021;21(4):1263. https://doi.org/10.3390/ s21041263.

43. Faiss R, Pialoux V, Sartori C, Faes C, Dériaz O, Millet GP. Ventilation, oxidative stress, and nitric oxide in hypobaric versus normobaric hypoxia. Med Sci Sports Exerc. 2013;45(2):253-60. https://doi.org/10.1249/MSS.0b013e31826d5aa2.

44. Fan JL, Subudhi AW, Evero O, Bourdillon N, Kayser B, Lovering AT, Roach RC. AltitudeOmics: enhanced cerebrovascular reactivity and ventilatory response to $\mathrm{CO} 2$ with high-altitude acclimatization and reexposure. J Appl Physiol (1985). 2014;116(7):911-8. https://doi.org/10.1152/japplphysiol.00704. 2013.

45. Fatemian M, Herigstad M, Croft QP, Formenti F, Cardenas R, Wheeler C, Robbins PA. Determinants of ventilation and pulmonary artery pressure during early acclimatization to hypoxia in humans. J Physiol. 2016;594(5):1197-213. https://doi.org/10. 1113/JP270061.

46. Faulhaber M, Pocecco E, Gatterer H, Niedermeier M, Huth M, Dünnwald T, Burtscher M. Seven passive 1-h hypoxia exposures do not prevent AMS in susceptible individuals. Med Sci Sports Exerc. 2016;48(12):2563-70. https://doi.org/10.1249/MSS. 0000000000001036 .

47. Fukuda R, Zhang H, Kim J-W, Shimoda L, Dang CV, Semenza GL. HIF-1 regulates cytochrome oxidase subunits to optimize efficiency of respiration in hypoxic cells. Cell. 2007;129(1):111-22.

48. Fulco CS, Beidleman BA, Muza SR. Effectiveness of preacclimatization strategies for high-altitude exposure. Exerc Sport Sci Rev. 2013;41(1):55-63. https://doi.org/10.1097/JES.0b013e3182 5 eaa33.

49. Fulco CS, Muza SR, Beidleman BA, Demes R, Staab JE, Jones JE, Cymerman A. Effect of repeated normobaric hypoxia exposures during sleep on acute mountain sickness, exercise performance, and sleep during exposure to terrestrial altitude. Am J Physiol Regul Integr Comp Physiol. 2011;300(2):R428-436. https://doi.org/10.1152/ajpregu.00633.2010.

50. Fulco CS, Muza SR, Beidleman B, Jones J, Staab J, Rock PB, Cymerman A. Exercise performance of sea-level residents at $4300 \mathrm{~m}$ after 6 days at $2200 \mathrm{~m}$. Aviat Space Environ Med. 2009;80(11):955-61.

51. Fulco CS, Rock PB, Cymerman A. Maximal and submaximal exercise performance at altitude. Aviat Space Environ Med. 1998;69(8):793-801. 
52. Gangwar A, Pooja, Sharma M, Singh K, Patyal A, Bhaumik G, Sethy NK. Intermittent normobaric hypoxia facilitates high altitude acclimatization by curtailing hypoxia-induced inflammation and dyslipidemia. Pflugers Arch. 2019;471(7):949-59. https:// doi.org/10.1007/s00424-019-02273-4.

53. Garvican L, Martin D, Quod M, Stephens B, Sassi A, Gore C. Time course of the hemoglobin mass response to natural altitude training in elite endurance cyclists. Scand J Med Sci Sports. 2012;22(1):95-103. https://doi.org/10.1111/j.1600-0838.2010. 01145.x.

54. Girard O, Brocherie F, Millet GP. Effects of altitude/hypoxia on single- and multiple-sprint performance: a comprehensive review. Sports Med. 2017;47(10):1931-49. https://doi.org/10. 1007/s40279-017-0733-z.

55. Girard O, Matic Girard I, Peeling P. Hypoxic conditioning: a novel therapeutic solution for load-compromised individuals to achieve similar exercise benefits by doing less mechanical work! Br J Sports Med. 2020. https://doi.org/10.1136/bjspo rts-2020-103186.

56. Girard O, Willis SJ, Purnelle M, Scott BR, Millet GP. Separate and combined effects of local and systemic hypoxia in resistance exercise. Eur J Appl Physiol. 2019;119(10):2313-25. https://doi. org/10.1007/s00421-019-04217-3.

57. Glazachev O, Kopylov P, Susta D, Dudnik E, Zagaynaya E. Adaptations following an intermittent hypoxia-hyperoxia training in coronary artery disease patients: a controlled study. Clin Cardiol. 2017;40(6):370-6. https://doi.org/10.1002/clc.22670.

58. Haase VH. Regulation of erythropoiesis by hypoxia-inducible factors. Blood Rev. 2013;27(1):41-53. https://doi.org/10.1016/j. blre.2012.12.003.

59. Haider T, Casucci G, Linser T, Faulhaber M, Gatterer H, Ott G, Bernardi L. Interval hypoxic training improves autonomic cardiovascular and respiratory control in patients with mild chronic obstructive pulmonary disease. J Hypertens. 2009;27(8):164854. https://doi.org/10.1097/HJH.0b013e32832c0018.

60. Hayashi T, Asano Y, Shintani Y, Aoyama H, Kioka H, Tsukamoto $\mathrm{O}$, Higo $\mathrm{S}$. Higd1a is a positive regulator of cytochrome $\mathrm{c}$ oxidase. Proc Natl Acad Sci. 2015;112(5):1553-8.

61. He S, Li J, Wang J, Zhang Y. Hypoxia exposure alleviates impaired muscular metabolism, glucose tolerance, and aerobic capacity in apelin-knockout mice. FEBS Open Bio. 2019;9(3):498-509. https://doi.org/10.1002/2211-5463.12587.

62. Heinzer R, Saugy JJ, Rupp T, Tobback N, Faiss R, Bourdillon N, Millet GP. Comparison of sleep disorders between real and simulated 3,450-m altitude. Sleep. 2016;39(8):1517-23. https:// doi.org/10.5665/sleep.6010.

63. Hilty MP, Hefti U, Brugger H, Bouzat P. Preacclimatization for expeditions to extreme altitude: an opinion position from the Union Internationale des Associations d'Alpinisme Medical Commission. High Alt Med Biol. 2020;21(3):303-4. https://doi. org/10.1089/ham.2020.0029.

64. Hobbins L, Girard O, Gaoua N, Hunter S. Acute psycho-physiological responses to perceptually regulated hypoxic and normoxic interval walks in overweight-to-obese adults. J Sci Med Sport. 2021;24(5):481-7. https://doi.org/10.1016/j.jsams.2020.11.011.

65. Hobbins L, Hunter S, Gaoua N, Girard O. Normobaric hypoxic conditioning to maximize weight loss and ameliorate cardiometabolic health in obese populations: a systematic review. Am J Physiol Regul Integr Comp Physiol. 2017;313(3):R251-64. https://doi.org/10.1152/ajpregu.00160.2017.

66. Jung ME, Simpkins JW, Wilson AM, Downey HF, Mallet RT. Intermittent hypoxia conditioning prevents behavioral deficit and brain oxidative stress in ethanol-withdrawn rats. J Appl Physiol (1985). 2008;105(2):510-7. https://doi.org/10.1152/japplphysi ol.90317.2008.
67. Katayama K, Sato K, Hotta N, Ishida K, Iwasaki K, Miyamura $\mathrm{M}$. Intermittent hypoxia does not increase exercise ventilation at simulated moderate altitude. Int J Sports Med. 2007;28(6):480-7. https://doi.org/10.1055/s-2006-955895.

68. Koller EA, Bührer A, Felder L, Schopen M, Vallotton MB. Altitude diuresis: endocrine and renal responses to acute hypoxia of acclimatized and non-acclimatized subjects. Eur J Appl Physiol Occup Physiol. 1991;62(3):228-34. https://doi.org/10.1007/ BF00643747.

69. Lee P, Chandel NS, Simon MC. Cellular adaptation to hypoxia through hypoxia inducible factors and beyond. Nat Rev Mol Cell Biol. 2020;21(5):268-83. https://doi.org/10.1038/ s41580-020-0227-y.

70. Lendahl U, Lee KL, Yang H, Poellinger L. Generating specificity and diversity in the transcriptional response to hypoxia. Nat Rev Genet. 2009;10(12):821-32. https://doi.org/10.1038/nrg2665.

71. Lenfant C, Sullivan K. Adaptation to high altitude. N Engl J Med. 1971;284(23):1298-309. https://doi.org/10.1056/NEJM197106 102842305.

72. Lenfant C, Torrance JD, Reynafarje C. Shift of the O2-Hb dissociation curve at altitude: mechanism and effect. J Appl Physiol. 1971;30(5):625-31. https://doi.org/10.1152/jappl.1971.30.5.625.

73. Levine BD, Zuckerman JH, deFilippi CR. Effect of high-altitude exposure in the elderly: the Tenth Mountain Division study. Circulation. 1997;96(4):1224-32.

74. Loeppky JA, Icenogle MV, Maes D, Riboni K, Hinghofer-Szalkay H, Roach RC. Early fluid retention and severe acute mountain sickness. J Appl Physiol (1985). 2005;98(2):591-7. https:// doi.org/10.1152/japplphysiol.00527.2004.

75. Loeppky JA, Scotto P, Roach RC. Acute ventilatory response to simulated altitude, normobaric hypoxia, and hypobaria. Aviat Space Environ Med. 1996;67(11):1019-22.

76. López-Laval I, Legaz-Arrese A, George K, Serveto-Galindo O, González-Rave JM, Reverter-Masia J, Munguía-Izquierdo D. Cardiac troponin I release after a basketball match in elite, amateur and junior players. Clin Chem Lab Med. 2016;54(2):333-8. https://doi.org/10.1515/cclm-2015-0304.

77. Luks AM. Clinician's corner: what do we know about safe ascent rates at high altitude? High Alt Med Biol. 2012;13(3):147-52. https://doi.org/10.1089/ham.2012.1055.

78. Lyamina NP, Lyamina SV, Senchiknin VN, Mallet RT, Downey HF, Manukhina EB. Normobaric hypoxia conditioning reduces blood pressure and normalizes nitric oxide synthesis in patients with arterial hypertension. J Hypertens. 2011;29(11):2265-72. https://doi.org/10.1097/HJH.0b013e32834b5846.

79. Lyons TP, Muza SR, Rock PB, Cymerman A. The effect of altitude pre-acclimatization on acute mountain sickness during reexposure. Aviat Space Environ Med. 1995;66(10):957-62.

80. Mairer K, Wille M, Bucher T, Burtscher M. Prevalence of acute mountain sickness in the Eastern Alps. High Alt Med Biol. 2009;10(3):239-45. https://doi.org/10.1089/ham.2008.1091.

81. Mallet RT, Manukhina EB, Ruelas SS, Caffrey JL, Downey HF. Cardioprotection by intermittent hypoxia conditioning: evidence, mechanisms, and therapeutic potential. Am J Physiol Heart Circ Physiol. 2018;315(2):H216-32. https://doi.org/10.1152/ajpheart. 00060.2018 .

82. Manukhina EB, Downey HF, Shi X, Mallet RT. Intermittent hypoxia training protects cerebrovascular function in Alzheimer's disease. Exp Biol Med (maywood). 2016;241(12):1351-63. https://doi.org/10.1177/1535370216649060.

83. Mazzeo RS, Bender PR, Brooks GA, Butterfield GE, Groves BM, Sutton JR, Reeves JT. Arterial catecholamine responses during exercise with acute and chronic high-altitude exposure. Am J Physiol. 1991;261(4 Pt 1):E419-424. https://doi.org/10.1152/ ajpendo.1991.261.4.E419. 
84. Mellor A. Research at high altitudes. J R Army Med Corps. 2011;157(1):5-7. https://doi.org/10.1136/jramc-157-01-01.

85. Millet GP, Debevec T. CrossTalk proposal: barometric pressure, independent of $\mathrm{PO} 2$, is the forgotten parameter in altitude physiology and mountain medicine. J Physiol. 2020;598(5):893-6. https://doi.org/10.1113/jp278673.

86. Millet GP, Faiss R, Pialoux V. Point: Hypobaric hypoxia induces different physiological responses from normobaric hypoxia. J Appl Physiol (1985). 2012;112(10):1783-4. https://doi.org/10. 1152/japplphysiol.00067.2012.

87. Millet GP, Faiss R, Pialoux V. Evidence for differences between hypobaric and normobaric hypoxia is conclusive. Exerc Sport Sci Rev. 2013;41(2):133. https://doi.org/10.1097/JES.0b013e3182 $71 \mathrm{a} 5 \mathrm{e} 1$.

88. Millet GP, Jornet K. On top to the top-acclimatization strategy for the "fastest known time" to Mount Everest. Int J Sports Physiol Perform. 2019. https://doi.org/10.1123/ijspp.2018-0931.

89. Millet GP, Roels B, Schmitt L, Woorons X, Richalet JP. Combining hypoxic methods for peak performance. Sports Med. 2010;40(1):1-25. https://doi.org/10.2165/11317920-00000 0000-00000.

90. Naeije R. Physiological adaptation of the cardiovascular system to high altitude. Prog Cardiovasc Dis. 2010;52(6):456-66. https://doi.org/10.1016/j.pcad.2010.03.004.

91. Netzer N, Strohl K, Faulhaber M, Gatterer H, Burtscher M. Hypoxia-related altitude illnesses. J Travel Med. 2013;20(4):247-55. https://doi.org/10.1111/jtm.12017.

92. Ogawa T, Fujii N, Kurimoto Y, Nishiyasu T. Effect of hypobaria on maximal ventilation, oxygen uptake, and exercise performance during running under hypobaric normoxic conditions. Physiol Rep. 2019;7(3): e14002. https://doi.org/10.14814/phy2. 14002.

93. Puissegur M, Mazure N, Bertero T, Pradelli L, Grosso S, RobbeSermesant K, Hofman V. miR-210 is overexpressed in late stages of lung cancer and mediates mitochondrial alterations associated with modulation of HIF-1 activity. Cell Death Differ. 2011;18(3):465-78.

94. Reynafarje C, Lozano R, Valdivieso J. The polycythemia of high altitudes: iron metabolism and related aspects. Blood. 1959;14(4):433-55.

95. Ricart A, Casas H, Casas M, Pagés T, Palacios L, Rama R, Ventura JL. Acclimatization near home? Early respiratory changes after short-term intermittent exposure to simulated altitude. Wilderness Environ Med. 2000;11(2):84-8. https://doi.org/ 10.1580/1080-6032(2000)011[0084:anherc]2.3.co;2.

96. Richalet JP. CrossTalk opposing view: barometric pressure, independent of. J Physiol. 2020;598(5):897-9. https://doi.org/ 10.1113/JP279160.

97. Richalet JP, Bittel J, Herry JP, Savourey G, Le Trong JL, Auvert $\mathrm{JF}$, Janin C. Use of a hypobaric chamber for pre-acclimatization before climbing Mount Everest. Int J Sports Med. 1992;13(Suppl 1):S216-220. https://doi.org/10.1055/s-2007-1024644.

98. Richalet JP, Pillard F, Le Moal D, Rivière D, Oriol P, Poussel M, Lhuissier FJ. Validation of a score for the detection of subjects with high risk for severe high-altitude illness. Med Sci Sports Exerc. 2020. https://doi.org/10.1249/MSS.0000000000002586 (Publish Ahead of Print)

99. Roach RC, Hackett PH, Oelz O, Bärtsch P, Luks AM, MacInnis MJ, Lake Louise AMS Score Consensus Committee. The 2018 lake louise acute mountain sickness score. High Alt Med Biol. 2018;19(1):4-6. https://doi.org/10.1089/ham.2017.0164.

100. Rodríguez FA, Casas H, Casas M, Pagés T, Rama R, Ricart A, Viscor G. Intermittent hypobaric hypoxia stimulates erythropoiesis and improves aerobic capacity. Med Sci Sports Exerc. 1999;31(2):264-8. https://doi.org/10.1097/00005768-19990 2000-00010.
101. Sato M, Severinghaus JW, Bickler P. Time course of augmentation and depression of hypoxic ventilatory responses at altitude. $\mathbf{J}$ Appl Physiol (1985). 1994;77(1):313-6. https://doi.org/10.1152/ jappl.1994.77.1.313.

102. Saugy JJ, Schmitt L, Hauser A, Constantin G, Cejuela R, Faiss R, Millet GP. Same performance changes after live high-train low in normobaric vs hypobaric hypoxia. Front Physiol. 2016;7:138. https://doi.org/10.3389/fphys.2016.00138.

103. Savourey G, Garcia N, Besnard Y, Hanniquet AM, Fine MO, Bittel J. Physiological changes induced by pre-adaptation to high altitude. Eur J Appl Physiol Occup Physiol. 1994;69(3):221-7. https://doi.org/10.1007/bf01094792.

104. Savourey G, Launay JC, Besnard Y, Guinet A, Travers S. Normo- and hypobaric hypoxia: are there any physiological differences? Eur J Appl Physiol. 2003;89(2):122-6. https://doi. org/10.1007/s00421-002-0789-8.

105. Sazontova T, Bolotova A, Bedareva I, Kostina N, Arkhipenko Y. Adaptation to intermittent hypoxia/hyperoxia enhances efficiency of exercise training. In: Xi L, Serebrovskaya T, editors. Intermittent hypoxia and human diseases. London: Springer; 2012a. p. 191-205.

106. Sazontova T, Glazachev O, Bolotova A, Dudnik E, Striapko N, Bedareva I, Arkhipenko I. Adaptation to hypoxia and hyperoxia improves physical endurance: the role of reactive oxygen species and redox-signaling. Ross Fiziol Zh Im I M Sechenova. 2012b;98(6):793-807.

107. Schega L, Peter B, Brigadski T, Leßmann V, Isermann B, Hamacher D, Törpel A. Effect of intermittent normobaric hypoxia on aerobic capacity and cognitive function in older people. J Sci Med Sport. 2016;19(11):941-5. https://doi.org/ 10.1016/j.jsams.2016.02.012.

108. Schommer K, Wiesegart N, Menold E, Haas U, Lahr K, Buhl $\mathrm{H}$, Dehnert $\mathrm{C}$. Training in normobaric hypoxia and its effects on acute mountain sickness after rapid ascent to $4559 \mathrm{~m}$. High Alt Med Biol. 2010;11(1):19-25. https://doi.org/10.1089/ham. 2009.1019.

109. Semenza GL. Hypoxia-inducible factors in physiology and medicine. Cell. 2012;148(3):399-408. https://doi.org/10. 1016/j.cell.2012.01.021.

110. Serebrovska TV, Grib ON, Portnichenko VI, Serebrovska ZO, Egorov E, Shatylo VB. Intermittent hypoxia/hyperoxia versus intermittent hypoxia/normoxia: comparative study in prediabetes. High Alt Med Biol. 2019;20(4):383-91. https://doi.org/ 10.1089/ham.2019.0053.

111. Serebrovskaya TV. Intermittent hypoxia research in the former soviet union and the commonwealth of independent States: history and review of the concept and selected applications. High Alt Med Biol. 2002;3(2):205-21. https://doi.org/10.1089/ 15270290260131939

112. Shah NM, Hussain S, Cooke M, O'Hara JP, Mellor A. Wilderness medicine at high altitude: recent developments in the field. Open Access J Sports Med. 2015;6:319-28. https://doi.org/10. 2147/OAJSM.S89856.

113. Sies H, Jones DP. Reactive oxygen species (ROS) as pleiotropic physiological signalling agents. Nat Rev Mol Cell Biol. 2020;21:363-83.

114. Song A, Zhang Y, Han L, Yegutkin GG, Liu H, Sun K, Xia Y. Erythrocytes retain hypoxic adenosine response for faster acclimatization upon re-ascent. Nat Commun. 2017;8:14108. https://doi.org/10.1038/ncomms14108.

115. Susta D, Dudnik E, Glazachev OS. A programme based on repeated hypoxia-hyperoxia exposure and light exercise enhances performance in athletes with overtraining syndrome: a pilot study. Clin Physiol Funct Imaging. 2017;37(3):276-81. https://doi.org/10.1111/cpf.12296. 
116. Swenson ER. Hypoxic pulmonary vasoconstriction. High Alt Med Biol. 2013;14(2):101-10. https://doi.org/10.1089/ham. 2013.1010.

117. Swenson ER, Bärtsch P. High-altitude pulmonary edema. Compr Physiol. 2012;2(4):2753-73. https://doi.org/10.1002/ cphy.c100029.

118. Tannheimer M, Lechner R. Rapid ascents of Mt Everest: normobaric hypoxic preacclimatization. J Travel Med. 2020. https://doi.org/10.1093/jtm/taaa099.

119. Taylor CT. Mitochondria and cellular oxygen sensing in the HIF pathway. Biochem J. 2008;409(1):19-26. https://doi.org/ 10.1042/BJ20071249.

120. Tello D, Balsa E, Acosta-Iborra B, Fuertes-Yebra E, Elorza A, Ordóñez Á, Perales-Clemente E. Induction of the mitochondrial NDUFA4L2 protein by HIF- $1 \alpha$ decreases oxygen consumption by inhibiting Complex I activity. Cell Metab. 2011;14(6):768-79.

121. Treml B, Kleinsasser A, Hell T, Knotzer H, Wille M, Burtscher M. Carry-over quality of pre-acclimatization to altitude elicited by intermittent hypoxia: a participant-blinded, randomized controlled trial on antedated acclimatization to altitude. Front Physiol. 2020;11:531. https://doi.org/10.3389/fphys.2020.00531.

122. Verges S, Chacaroun S, Godin-Ribuot D, Baillieul S. Hypoxic conditioning as a new therapeutic modality. Front Pediatr. 2015;3:58.

123. Vizcardo-Galindo G, León-Velarde F, Villafuerte FC. High-altitude hypoxia decreases plasma erythropoietin soluble receptor concentration in lowlanders. High Alt Med Biol. 2020;21(1):92 8. https://doi.org/10.1089/ham.2019.0118.

124. Weidemann A, Johnson RS. Biology of HIF-1alpha. Cell Death Differ. 2008;15(4):621-7. https://doi.org/10.1038/cdd.2008.12.

125. Weil JV, Byrne-Quinn E, Sodal IE, Friesen WO, Underhill B, Filley GF, Grover RF. Hypoxic ventilatory drive in normal man. J Clin Invest. 1970;49(6):1061-72. https://doi.org/10.1172/JCI10 6322.

126. Wilber RL. Current trends in altitude training. Sports Med. 2001;31(4):249-65.

127. Wilber RL. Application of altitude/hypoxic training by elite athletes. Med Sci Sports Exerc. 2007;39(9):1610-24. https://doi org/10.1249/mss.0b013e3180de49e6.

128. Wille M, Gatterer H, Mairer K, Philippe M, Schwarzenbacher H, Faulhaber M, Burtscher M. Short-term intermittent hypoxia reduces the severity of acute mountain sickness. Scand J Med Sci Sports. 2012;22(5):e79-85. https://doi.org/10.1111/j.1600-0838. 2012.01499.x.

129. Zon LI, Youssoufian H, Mather C, Lodish HF, Orkin SH. Activation of the erythropoietin receptor promoter by transcription factor GATA-1. Proc Natl Acad Sci USA. 1991;88(23):10638-41. https://doi.org/10.1073/pnas.88.23.10638.

130. Zouboules SM, Lafave HC, O'Halloran KD, Brutsaert TD, Nysten HE, Nysten CE, Day TA. Renal reactivity: acid-base compensation during incremental ascent to high altitude. J Physiol. 2018;596(24):6191-203. https://doi.org/10.1113/JP276973. 